\title{
DECOMPOSITION OF RUSSIA'S GDP GROWTH RATE AND GDP DYNAMICS FACTORS IN 2015
}

\author{
S.Drobyshevsky, M.Kazakova
}

The results of the estimates made using a method developed by the Gaidar Institute for decomposing Russia's GDP growth rates show that economic contraction in 2015 is determined by structural causes, according to the two scenarios within an updated forecast of the Ministry of Economic Development (MED). The structural causes are contraction of the fundamental growth factors (labor force and capital) as well as stagnation of the Total Factor Productivity, with a negative contribution of the other GDP growth rate components. In particular, the MED projects that the average annual price of crude oil in 2015 will be less than the long-time average annual, hence the foreign-trade component of GDP growth rates becomes negative in both forecast scenarios. The market-determined component of GDP growth rates in 2015 will continue to be negative and even decline compared to 2014, indicating that cyclical shrinkage of the Russian economy will increase. At the same time, a negative value of the output gap is indicative of that actual GDP will be less than potential GDP in 2015.

In May 2015, some of high-ranking representatives of the Russian government and business community (in particular, First Vice-Prime Minister Igor Shuvalov and Sberbank CEO/Chairman Herman Gref) said that the peak of the current crisis had been reached and the economic situation is expected to improve in the second half of the year. Furthermore, the Russian Ministry of Economic Development and a series of international organizations (Bank of America, JP Morgan, IMF, and World Bank) upgraded their forecasts for 2015.

In our opinion, it is not quite realistic to expect the Russian economy to grow in the foreseeable future, because the key GDP growth factors are facing a downtrend. These factors can be identified using a method we suggest, which is based on the method applied in developed countries (OECD) for decomposing macroeconomic indicators into their structural, foreigntrade, and market-determined (business cycles and random shocks) components. Our method is adapted to the specific features of the Russian economy which depends largely on foreign trade trends approximable through the dynamics of global crude oil prices.

Russia's GDP actual, structural, foreign-trade growth rate and market-determined component (i.e. the sum of the components of business cycles and random shocks) are shown in Figs. 1 and 2. The estimates herein are based on the updated forecast made by the Ministry of Economic Development (MED) for 2015. The forecast includes two scenarios: the first (baseline) scenario expects that GDP will see a YoY decline by $2.8 \%$ and investment by $10.6 \%$, with crude oil being priced $\$ 50$ per barrel, whereas the second (optimistic) scenario expects GDP to fall by $2.5 \%$ and investment by $8.7 \%$, with crude being priced $\$ 60$ per barrel.

According to our estimates, the structural component will decline slightly this year (to 1.1\% in 2015

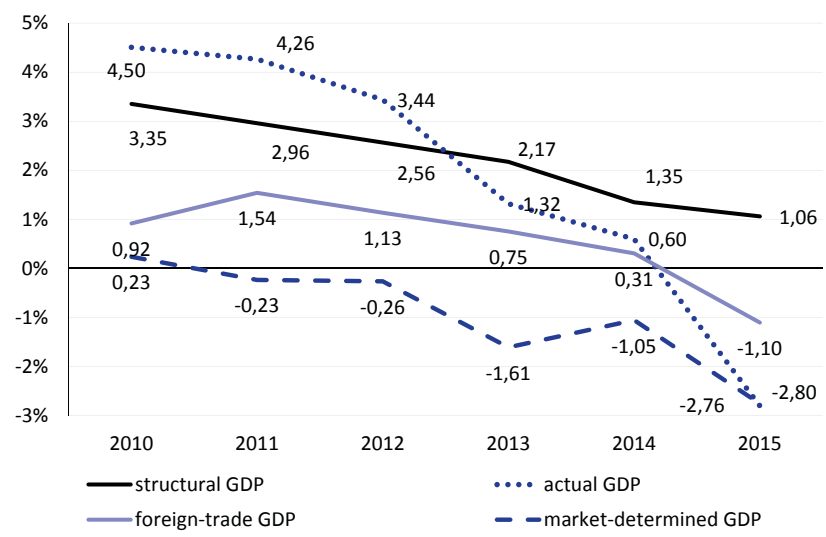

Sources: Russia's Federal State Statistics Service (Rosstat), Russia's Ministry of Economic Development (MED), IMF, the authors' estimates.

Fig. 1. Actual, structural, foreign-trade, and marketdetermined growth rates of GDP, \% YoY, 2010 - 2015 (forecast for the baseline scenario)

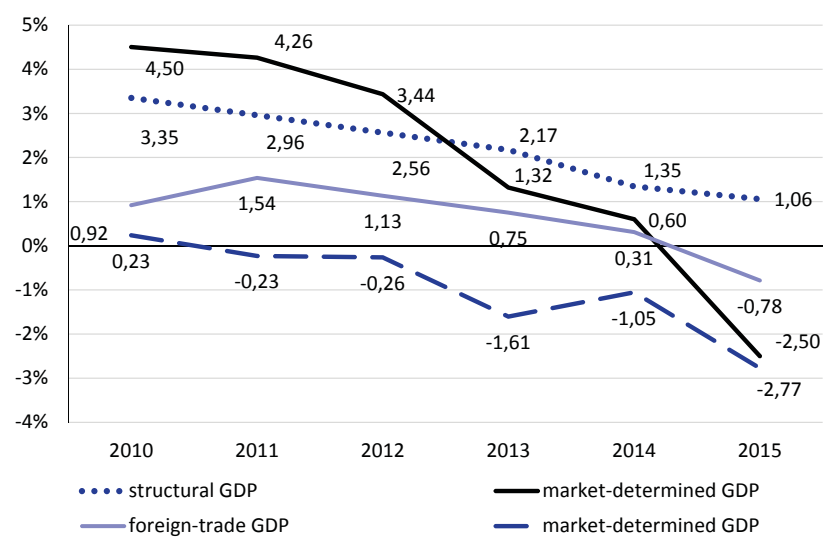

Source: Rosstat, MED, IMF, authors' estimates.

Fig. 2. The actual, structural, foreign-trade, and market-determined growth rates of GDP, \% YoY, 2010-2015 (forecast for the optimistic scenario) 
from $1.3 \%$ in 2014, Fig. 1) due to negative dynamics of the fundamental factors of growth (contraction of the workforce due to demographic trends and the volume of capital due to retirement amid investment negative dynamics).

The negative foreign trade component of Russia's GDP growth rates in 2015 for both scenarios (-1.1 and $-0.8 \%$, respectively) is determined by the fact that drastic worsening of the terms of trade (a fall of crude oil prices to $\$ 50$ and $\$ 60$ per barrel, respectively) will push the actual price below the long-time average annual (about $\$ 86$ per barrel.).

Figs. 1 and 2 show that the market-determined component of Russia's GDP growth rates in 2015 will stay negative in both scenarios, with the cyclical downturn in the Russian economy increasing this year compared to 2014.

The gap in the Russian economic output in 2015 resulted from the decomposition of Russia's GDP growth rates will be negative for the first time since 2000 (Fig. 3). The negative gap is caused by negative contribution of two components (the foreign-trade and market-determined components, with the negative contribution by the latter for the last five years since 2011), with structural growth rates slowing down.

Hence the actual output in 2015 in both scenarios appears to be less than the potential one. In terms of economics, incentive measures of monetary and fiscal policies in this case may have, at least for a short period of time, a positive effect on the economy. However, an increase in long-term economic growth rates will first require a boost in structural rates based on the fundamental factors of growth and the Total Factor Productivity (TFP). In modern economic environment

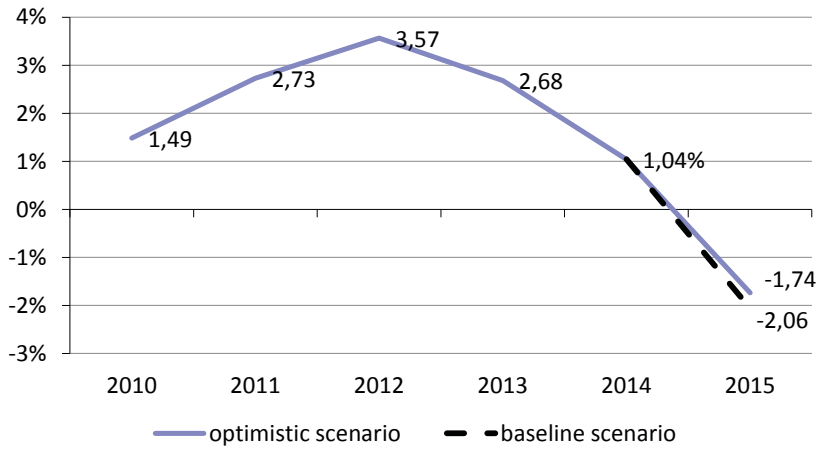

Source: the authors' estimates.

Fig. 3. The Russian economy output gap (\%), 2010-2015 (forecast for both scenarios)

this suggests that changes should be made in order to make foreign capital available for Russian companies; foreign direct investment; more domestic investments by Russian business entities, and relaxing the limits on available labor resources.

The foregoing measures will enhance the efficiency of using production factors (i.e. TFP growth). Efficient institutions is the only way to stimulate new production factors and structural reforms (including diversification of the economy and making it less dependent on exports of raw materials), and investment in the economy (the transport infrastructure, social protection, etc.) will increase economic growth and maintain steady growth rates in the long run ${ }^{1}$.

1 A more detailed description of the method of decomposing Russia's GDP growth rates, as well as the interpretation of the results we obtained is available in the article written by SinelnikovMurylev S.,Drobyshevskiy S., Kazakova M. Decomposition of Russia's GDP growth rates in 1999-2014 // Ekonomicheskaya Politika. 2014. No. 5. Pp. 7-37, and at http://iep.ru/ru/publikatcii/7125/publication.html 